\title{
1. Introduction to A Modern Guide to Economic Sociology
}

Milan Zafirovski

\section{GENERAL CONSIDERATIONS}

This volume provides a modern guide to the fundamental concepts, premises and findings of economic sociology within sociological theory and research and its elements and implications in theoretical and empirical economics. Accordingly, it invites and includes contributions from both modern economic sociologists and contemporary sociologically minded - especially institutional, social, political, behavioral and cognitive - economists doing theoretical or empirical work in this and closely related fields.

In general, the concepts, premises and stages of economic sociology within sociological theory and research tend to correspond and converge with its elements and implications in theoretical and empirical economics. Thus, the fundamentals and main developments of economic sociology within sociological analysis appear to be generally compatible with the variations and tendencies in economics. Almost every major concept, premise and stage of economic sociology corresponds, converges and is essentially compatible in various degrees and ways with an element, implication and phase of it in economics, primarily social, institutional, political, behavioral and related economics. This can be considered and formulated as a high degree of correspondence, convergence and compatibility between economic sociology within sociological theory and research and its elements and approximations in theoretical and empirical economics with respect to a shared set of core concepts and premises, as well as a common sequence of phases of development. And this shared set of core principles or a common sequence of phases primarily makes sociology and economics 'sister disciplines' or 'allied' social sciences, probably more than any other ideas or methods do (including 'rational choice theory' or the universal 'economic approach to human behavior' extending from the second to the first discipline).

For illustration, the original, classical idea, premise and phase of economic sociology in sociological theory since Auguste Comte and perhaps even earlier 
social thought (e.g., Montesquieu; Saint Simon) corresponds, converges and is essentially compatible with its elements or implications in classical political economy, including Adam Smith, in part Ricardo, and especially J. S. Mill. (See Bladen 1941; Coase 1978; Davis 1945; North 1915; Parsons 1935; Reisman 1987; Schumpeter [1911] 1949a, 1949b; Sen 1994; Smelser and Swedberg 2005; yet also see Granovetter and Swedberg 1992.) Similarly, the later mature classical concept, principle and stage of economic sociology in Durkheim, Weber and Pareto (the sociologist) stands in such a relation to its elements and approximations in sections of neoclassical economics, including Jevons, Walras and Marshall, as well as a fortiori to those in historical, original (Veblenian) institutional and generally social economics. (See Bladen 1941; Burgenmeier 1994; Coase 1978; Davis 1945; Furubotn and Richter 2010; Hamilton and Feenstra 1998; Hodgson 1998; Reisman 1990; Rutherford 2001; Sandmo 2007; Schumpeter 1941; Swedberg 1998.) The same pattern of complementarity and convergence holds for the early modern idea, premise and phase of economic sociology in Parsons et al. and its variations in early contemporary economics, especially Schumpeter and other sociologically minded economists of that time (Arrow 1994; Boulding 1970; Knight 1958; Myrdal [1930] 1953; see also, MacDonald 1965; Swedberg 1991). Lastly, its modern idea, principle and stage, often termed the new economic sociology, complements, corresponds and to a large extent converges with its elements and ramifications in later contemporary or current economics (Akerlof 2002; Granovetter 2005; Jackson 2014; Smelser and Swedberg 2005; Swedberg 2003; Williamson 1998).

The expression and result of the above pattern is a set of essential concepts and ideas and of main premises and principles that the preceding stages and types of economic sociology within sociological analysis share with its variations and approximations in economics. For example, early classical economic sociology and classical political economy (e.g., Comte explicitly and J. S. Mill by implication) share the concept of 'social economy' as involved in society and the premise of the social constitution and determination of economic activities and outcomes. In a similar vein, later classical economic sociology shares with parts of neoclassical economics - for example, Durkheim, Weber and Pareto with Jevons, Walras and Wicksell - the idea of social economy, and especially the assumption of the social, notably institutional, framework and conditioning of economic behaviors and processes with original institutional economics represented by Veblen and others. Furthermore, early modern economic sociology and segments of early contemporary economics, including Parsons and Schumpeter, respectively, share the idea of a sociological treatment of the economy and the assumption of the social, including institutional, structure and determination of economic actors and actions. Finally, later modern or the new economic sociology shares the idea of a sociological 
analysis of the economy and the conception of social constitution and conditioning - simply restated as embeddedness - of economic agents, actions and outcomes with much of current, especially institutional and social, economics.

In sum, the key ideas, premises and stages of economic sociology often complement, correspond and converge with its elements and implications in economics. This yields a shared set of concepts, assumptions and findings such as the concept of a social economy and the assumption and finding of the social, including institutional, political and cultural, constitution and determination (simply embeddedness) of economic actors, behaviors, processes and outcomes.

\section{EARLY CLASSICAL ECONOMIC SOCIOLOGY AND CLASSICAL POLITICAL ECONOMY}

As noted, the original classical idea, premise and phase of economic sociology in sociological theory corresponds, converges and to some degree overlaps with its elements and implications in classical political economy as from the 1830s through the 1870s. In a sense, early classical economic sociology from Comte (and perhaps Montesquieu and Saint Simon) is compatible, convergent and complementary with the broader social dimension of classical political economy since Adam Smith and even earlier (e.g., Francois Quesney) (Smelser and Swedberg 2005). This holds insofar as classical political economy, while being primarily what Schumpeter (1956) denotes a 'theory of market economics' and Robbins (1981) calls catallactics or the 'Science of Exchanges', also represents 'social economics', with J. B. Say as an example, and to some degree prefigures 'sociological economics', as in the case of Smith (Forget 1999; Reisman 1987). Schumpeter ([1911] 1949a, p. 60) identifies the 'economic sociology of Adam Smith' (even if he never used the term 'sociology'), identifying its 'most important elements', such as 'division of labor, the origin of private property, increasing control over nature, economic freedom, and legal security', in that all these phenomena 'relate to the social framework of the economic course of events'.

Further, Parsons (1935, p. 427) identifies an instance of 'sociological elements' in classical political economy, even in Ricardo's putatively purest economic analysis, such as the 'habits and customs of the people' as an 'important factor' in the economy (also, North 1915). In this connection, Ricardo ([1846] 2010 , p. 58) specifically adopts this seemingly institutional-social factor to explain wages, stating that the 'natural price of labour' ('estimated even in food and necessaries') is not 'absolutely fixed and constant. It varies at different times in the same country, and very materially differs in different countries. It essentially depends on the habits and customs of the people.' Furthermore, even Senior ([1836] 1951, p. 151), whom Samuelson (1994) primarily includes 
among the 'classical apologists' of capitalists, admits that while the laws that relate to 'Nature and Production of Wealth are universally true', those relating to 'Distribution of Wealth are liable to be affected by the peculiar institutions [e.g., slavery, legal monopolies, or poor laws].'

In general, such a compatibility and complementarity between early classical economic sociology and classical political economy rests on and revolves around the concept of 'social economy' that the first discipline typically postulates and elaborates and the second occasionally adopts or implies. More specifically, Comte explicitly constructs and develops the concept of social economy, as well as derives its consequences for economic and sociological analysis in early classical sociology, which some classical and even neoclassical economists (e.g., Wicksteed) accept and explicitly invoke, along with later classical sociologists, including Durkheim and Weber (Granovetter and Swedberg 1992; Swedberg 1998). In particular, Comte's partial follower J. S. Mill embraces and establishes even if by implication the concept and its analytical or theoretical consequences within later classical political economy (Bladen 1941). ${ }^{1}$

Comte ([1839] 1983, p. 186) conceives of a 'good social economy' in the sense of an economy that is a constitutive component as well as a function of society, thus as an economic system being invariably an integral element and mostly a dependent variable of the social system. This concept relates to but is distinct from J. B. Say's ([1828] 1852, p. 1) notion of 'social economy'. The latter is a 'better' name for political economy, the study of the 'nature and function of different parts of the social body', simply the 'economy of the society' (l'économie de la société) or of (political) societies in the apparent sense of economics rather than Comte's societal economy, although it can be interpreted in this way (Forget 1999). Still, on other occasions Say ([1828] 1852 , p. 49) clearly understands 'social economy' as the economy - and not the economics - of society, as when stating that the object of economic science is to study the 'social economy, in this world', thus implying or converging with Comte's explicit sociological concept of the economy. Comte consistently conceptualizes 'social economy' as an ontological category and real-life domain of sociological-economic analysis, while Say pursues both this conceptualization (the 'social economy, in this world') and that in epistemological terms as economic epistemics (the 'economics of society') (also, Lawson 1997; Shackle 1972).

Consequently, Comte ([1839] 1983, p. 274) implicitly defines economic sociology, and even sociology as a whole, as an 'inquiry into the social economy'. This includes the necessity or possibility of government intervention in the 'performance of all the various functions of the social economy' in the aim of sustaining the 'idea of the whole, and the feeling of common interconnection' in society. In this connection, Comte effectively posits the 
classical sociological principle of societal constitution or framework and determination or conditioning of the economy as well as anticipates modern economic sociology's cognitive corollary conception of social embeddedness of economic actors and processes (Granovetter and Swedberg 1992). Comte ([1839] 1983, p. 276) observes that the 'natural course' and the 'various functions of the social economy' tend to be 'naturally implicated' in society ('relations of greater generality'). Consequently, they are to be invariably placed under the 'direction of the most general function of all' involving the 'constant action of the whole', the social system, including its polity, on its component parts. Comte ([1839] 1983, p. 224) therefore suggests that the 'laws of action and reaction of different parts of the social system' which the 'static study of sociology' investigates comprise the 'whole social economy' as one of these societal parts. In theoretical terms, Comte can hence be credited with founding or anticipating the systems theory of the economy and society as the part and whole, respectively, that later economic sociologists from Durkheim and Pareto to Parsons et al. adopt and develop, and even some contemporary economists accept or imply, as seen later. In historical terms, Comte differentiates the 'social economy of antiquity' or the 'ancient social economy' involving slavery and war from the modern 'social economy', presumably dispensing with the last two regimes and incorporating, for example, art as a new addition that has been excluded previously.

Mill implicitly adopts and elaborates Comte's concept of social economy, as well as explicitly notes and reconsiders Say's idea of 'social economy' as a 'better' name for political economy in the sense of economic science. Mill ([1874] 1974, p. 135) implies Comte's sociological concept as well as Say's alternative ontological notion of social economy by referring to the 'social state' of economy that exists in 'a state of society' and is subject to the 'laws of society' expressing the 'laws of human nature in the social state' and distinguishes it from its pre-social state. More specifically, Mill ([1874] 1974, p. 133) implicitly defines the social economy in terms of 'production and distribution of wealth' only in a 'social state', and not in 'all states of mankind', especially pre-social conditions. Mill ([1874] 1974, p. 136) by implication characterizes economic sociology à la Comte under the name or proxy of the 'science of social economy' as a study of the laws of wealth production and distribution only 'in a state of society' and thus of the societal constitution and determination of these and other economic processes.

In addition, other early classical sociologists and economists imply or adopt from Comte and Mill the concept of social economy as an economic system and a component and function of society. For example, Spencer ([1850] 1970), in early classical sociology, uses the term 'our social economy' and proposes that it be imbued with both 'conservative' and 'reforming' forces. Cairnes ([1874] 1967, p. 68), as the 'last important' representative of mature classical 
political economy, specifically finds it compelling to recognize the 'existence of non-competing industrial groups as a feature of our social economy' (also, Stigler 1957). In turn, within both classical sociology and economics, Marx ([1859] 1970) (if considered an economist and sociologist alike), while not using the term explicitly, clearly implies and indeed emphasizes the social economy by adopting and emphasizing such concepts as the 'social process of production', 'social production', capital as 'social property' and the like.

Accordingly, the concept of social economy by Comte makes the early classical idea, premise and phase of economic sociology correspond, converge and indeed virtually overlap with its elements or ramifications in classical political economy since Mill, just as Comte inspires its formulations by later major sociologists like Durkheim and Weber. By suggesting the earliest classical concept of economic sociology as the study of the social economy implicated in the whole social system, Comte converges with and probably influences, along with Say, Mill in proposing a 'science of social economy', that is, the economy in the 'state of society', as distinct from, and notably broader than, conventional political economy. Alternatively, Mill's 'science of social economy' embraces and restates Comte's substantive economic sociology. This is what Schumpeter (1949b) suggests by identifying a significant share of economic sociology in Mill's main economics work Principles of Political Economy.

Relatedly, Comte's original concepts of social statics and social dynamics as branches of sociology, including the study of the 'social economy', complement and indeed lead to Mill's notions of economic statics and economic dynamics, who admittedly borrowed these sociological ideas and introduced them to classical political economy and thus economics, as Schumpeter $(1954)^{2}$ notes (also, Hayek 1950). Hence, social statics and dynamics extend and ramify from classical economic and general sociology through Mill's economic statics and dynamics to J. B. Clark's (1899) neoclassical 'theory of Economic Statics' and 'theory of Economic Dynamics' as a division of economic science premised on 'sociological evolution' apparently in the spirit of Comte. Further, they expand beyond into modern economics, as in the form of 'comparative' statics and dynamics (Samuelson 1983; also, Backhouse 2015). Furthermore, apparently embracing Comte's ideal of unification via a single science of society, Mill ([1874] 1974, p. 156) incorporates political economy into the 'branches of social philosophy' in the apparent Comtean sense of sociology.

Similarly, even if less explicitly, the early classical idea, principle and stage of economic sociology corresponds, converges and often overlaps with its elements or approximations in such other versions of classical political economy as those of Marx (the economist) and to some degree Cairnes. Comte's conception of economic sociology as an 'inquiry into the social economy' 
appears generally compatible with, regardless of some particular differences from, Marx's rendition of political economy as the analysis of the 'social process of production' as well as with Cairnes's study of the 'social economy' (Granovetter and Swedberg 1992; Smelser and Swedberg 2005; also, Stigler 1957).

In sum, early classical economic sociology and later classical political economy share or approach a set of basic common concepts, ideas or terms and of main premises, principles or assumptions. The basic common concept is that of a social economy regarded as a part of society and, as a corollary, the main shared premise is that of the societal constitution and determination of economic processes.

\section{LATER CLASSICAL ECONOMIC SOCIOLOGY AND NEOCLASSICAL ECONOMICS}

Continuous with the previous early classical economic sociology, the mature classical idea, premise and stage of economic sociology corresponds and converges with its elements and implications in sections of neoclassical economics from the 1870-80s through the 1920-30s. This holds even more for economic sociology in relation to its analogues in historical, original institutional and other unorthodox economics outside and beyond its neoclassical or orthodox counterpart. Likewise, later classical economic sociology is compatible and complementary especially with the broader social dimension of neoclassical economics in its secondary but integral and relatively salient dimension of 'social economics'. Thus, some analysts identify 'sociological elements', specifically those of 'economic sociology', 'sociological economics' and 'socio-economics', as distinct from but connected with the core of 'pure' economics in such eminent neoclassical economists as Alfred Marshall and Leon Walras (Bladen 1941; Burgenmeier 1994; Furubotn and Richter 2010; Parsons 1935; Reisman 1990; Schumpeter 1941).

In a manifest continuity, this compatibility and complementary between mature classical economic sociology and its elements in neoclassical economics continues to revolve around the concept of 'social economy'. Later classical economic sociology inherits and elaborates the concept from its earlier version in Comte, while neoclassical economics inherits it from classical political economy, especially Mill and Say. This holds in general with some particular subtle differences in that mature classical economic sociology continues to operate with the concept of social economy as mostly an economic system and an integral element and function of society, thus as an ontological category, aside from certain exceptions. Segments of neoclassical economics instead understand 'social economy' mostly in the sense of 'social economics' that is deemed a conception or branch of economic science by analogy and in 
addition to 'pure' political economy or economic theory and to that extent considered as an epistemic concept, apart from some mostly implicit exceptions.

Especially Durkheim, Pareto and to some degree Weber in mature classical sociology, adopt and elaborate the Comtean systemic treatment of the concept in terms of an economic system and a part and dependent variable of the total social system as a broader and more complex category, that is, the systems theory of economy and society (Granovetter and Swedberg 1992). ${ }^{3}$ Thus, Durkheim ([1912] 1976, p. 112) understands the 'social economy' in the sense of an economic system of society, including the presumed 'superiority' of the 'social economy' of some tribal societies. Relatedly, Durkheim ([1895] 1982, pp. 172-4) considers the economy to be primarily a dependent variable in relation to society, including culture such as religion, rather than conversely, and hence a social economy, in a criticism of the 'materialist conception of history', postulating that all societal phenomena depend on the 'economic factor'.

In a similar vein, Pareto ([1909] 1927, p. 429) regards the 'social economy' as the type of economy and a constitutive component of society involving 'mutability' in diverse forms, especially 'violent revolutions' through class or elite conflicts. Like Comte, Pareto ([1916] 1932, p. 1313) treats the 'states' of the economy as 'particular cases' of the general state of the 'sociological system' in the sense of the social system as a more comprehensive order. Furthermore, Pareto ([1916] 1932, pp. 1594, 2315) characterizes the sociological or social system as 'much more complicated' than the economic system, by virtue of involving not only rational forces ('appetites and interests') and logical actions, as does the economy, but also and indeed predominantly non-rational forces ('residues and derivations') and non-logical actions. Accordingly, Pareto ([1916] 1932, pp. 1594-5) infers that a 'greater complication' arises in economic and general sociology due to adding 'non-logical actions' to the 'logical actions' that conventional economics only considers and illogical 'derivations' to 'logical-reasoning'.

In turn, Weber ([1905] 1949, p. 65) refers to the 'science of social-economics' (since Marx and Roscher) that investigates not only purely economic phenomena but also those social phenomena and relations that are 'economically relevant' and 'economically conditioned', thus its domain being 'almost overwhelming'. Accordingly, Weber ([1921-22] 1968, pp. 68, 79) conceives social economy, or rather social economics (Sozialökonomie), as an integral economic science to encompass economic theory and the 'field of economic sociology', along with economic history. In Weber's view, while economics' 'theoretical insights' ground 'a sociological theory' or 'sociology of economic action', economic sociology may build its own 'theoretical constructs' to substitute for the assumption of actors' isolation in conventional economics (also, Schumpeter 1954; Swedberg 1998). In particular, Weber ([1921-22] 
1968, p. 81) identifies the 'sociology of the market' within the framework of 'economic sociology' and thus social economics.

In neoclassical economics, some of its prominent figures, such as Walras, Wicksell and Wieser, treat 'social economy' as a special branch of economic science, along with 'pure' as well as applied economics. Thus, Walras ([1874] 1926, p. 5; [1896] 1936a, p. 120) treats 'social economy' as one of the 'three parts' of economic science and defines it as the 'theory of distribution of social wealth by property and taxation', briefly, the 'theory of division of social wealth'. Relatedly, Walras ([1874] 1926, pp. vi, xi; also, [1898] 1936b) characterizes 'pure' political economy as the 'theory of social wealth' as well as the 'theory of the determination of prices under the hypothetical regime of absolutely free competition'. In addition, he describes applied political economy as the 'theory of agricultural, industrial and commercial production of social wealth', simply the 'theory of production of social wealth'. Replicating Walras, Wicksell ([1901-06] 1934-35, p. 5) characterizes 'social economy' as 'an investigation of the issue of how economic laws and practical precepts would be properly applied for getting the most possible social gain, and what changes in the existing economic and legal structure of society are necessary for this end'. Like Walras, Wicksell distinguishes social economy from pure or theoretical political economy and applied political economy. Wieser ([1914] 1967, pp. 152-3) also constructs 'social economics' as a special branch of economics consisting of an 'inquiry into the social relations of the economy' and involving the 'sociological problems of economic theory', thus as substantively equivalent to economic sociology and narrower than Weber's integral conception of the 'science of social-economics'. Furthermore, Cassel (1929) expounds economics as 'social economy' that hence becomes the essential field or the appropriate designation of the latter, which is fully consistent with what denotes the 'social economy' as a real-life economic system in Comte's sociological meaning and the inherent subject of economic science.

From the standpoint of economic sociology, the preceding distinction between 'social economy' as an economic system of society in classical sociology, except partly for Weber, and 'social economics' as a particular branch or version of economic science within neoclassical economics appears a minor and semantic, almost impertinent difference that is analogous to that between 'economy' and 'economics'. This holds as long as both later classical economic sociology and neoclassical 'social economics' seek to find their ground and rationale in the concept and indeed real existence and salience of a 'social economy' in the sense of an economy of society and thus an integral element and, to an important degree, function of the larger social system.

Furthermore, the mature classical idea, principle and stage of economic sociology sometimes finds its explicit expression in, and thus virtually overlaps with, neoclassical economics. For example, both Durkheim and Weber 
within classical sociological theory and Jevons in neoclassical economics explicitly adopt the concept of and indeed the very term 'economic sociology'. Durkheim ([1909] 1994) specifies the 'subject matter of economic sociology' as encompassing 'economic institutions', such as 'institutions relating to the production of wealth', 'institutions relating to exchange' and 'institutions relating to distribution'. As seen, Weber conceives economic sociology as the 'sociology of economic action' and particularly 'a sociological theory of economic action', including the 'sociology of the market'. Pareto ([1916] 1932, p. 1317) clearly implies economic sociology when stating that the study of many economic phenomena is incomplete and indeed impossible 'without the aid of sociology'.

While Comte invents the concept in the sense of a sociological analysis of a 'social economy' existing and functioning within and conditioned by the 'social system', under his apparent influence and that of Spencer's sociology, Jevons probably invents the very term 'economic sociology' sometime prior to Durkheim, Weber and other later classical sociologists (Swedberg 1998). Moreover, these sociologists and Jevons, and even some other neoclassical economists, converge on economic sociology not just nominally but also in substantive terms. Thus, not only do Durkheim, Weber, Pareto and other later classical sociologists consider it an essential field of sociology, but also Jevons ([1879] 1965, pp. 20-21) assigns to 'a branch of economic sociology', along with some other branches, the mission of rescuing economics from its 'confused state'. Jevons ([1879] 1965, p. 20) implicitly constructs economic sociology as the study of social processes and relations in the economy by referring to Spencer's 'Sociology' as the 'Science of the Evolution of Social Relations'. Wicksteed ([1910] 1933, p. 784) infers from that that the economy is a component and function of society ('the better we understand the true function of the market in its widest sense, the more fully shall we realize that it never has been left to itself, and the more deeply shall we feel it never must be') and therefore economics 'must be a handmaid of sociology'. ${ }^{4}$ Moreover, Wicksteed ([1910] 1933, p. 1) opens his main work (The Common Sense of Political Economy) by citing Comte's following statement (in French without translation) pertaining to the relation between economic and sociological analyses: 'economic analysis proper must not be conceived and cultivated either theoretically or historically apart from the whole of sociological analysis either static or dynamic.'

Jevons's other follower, Edgeworth ([1881] 1967, p. 109), in a somewhat obscure statement explicitly referring to Comte, describes marginal economics (the Calculus of Variations in utility) as the 'branch most applicable to Sociology'. Marshall ([1891] 1961, p. 618) also mentions Comte and acknowledges 'some excellent intensive studies' under the 'name of Sociology' (albeit he doubts its attempts 'a unification of social sciences'). Moreover, Schumpeter 
(1941) identifies 'an economic sociology of 19th-century English capitalism' with 'historical bases of impressive extent and solidity' in Marshall's main work Principles of Economics (also, Bladen 1941; Furubotn and Richter 2010; Parsons 1932). Marshall's contemporary and early follower J. N. Keynes ([1890] 1955, p. 145) specifically finds that the 'theory of economic progress' is, within economics, especially 'subordinate' to 'general sociology' and thus involves economic sociology with respect to this progress.

At this point, economic sociology declaratively enters into and becomes a branch of economics even in its neoclassical stage, just as it substantively remains the field of mature classical sociology after Comte. It appears that these later classical sociologists and early neoclassical economists reach a kind of consensus or strong convergence on the idea of economic sociology and its character, place and importance in relation to and within economics, respectively. In retrospect, the above case joining Durkheim, Weber and Pareto (the sociologist) with Jevons, Wicksteed and to some degree Edgeworth and Marshall qualifies as probably the most manifest and explicit example in which the mature classical idea, premise and stage of economic sociology corresponds and converges with its concept, (implicit) definition and term in parts of neoclassical economics. (This resembles the convergence thesis with regard to Durkheim, Weber, Pareto and Marshall in Parsons [1937] 1967.) This striking example seems analogous to and notably continuous with the link or convergence between Comte and Mill with respect to economic sociology and social economy during the earlier stages of both disciplines (Bladen 1941; Schumpeter 1954).

More broadly and frequently, the mature idea, premise and stage of classical economic sociology corresponds and converges with its analogues or proxies in neoclassical economics, both having their basis in the concept of 'social economy' in the sense of an economic subsystem of the societal system. As noted, classical economic sociology's principal apparent analogue in neoclassical economics is 'social economy' in the alternative epistemic meaning - similarly to 'political economy' - of a particular conception or branch of economic science, simply 'social economics' as a science. For example, the economic sociology of Durkheim, Weber, Pareto and other later classical sociologists is complementary and compatible with the explicit 'social economy' of Walras, Wicksell and Cassel and the 'social economics' of Wieser as a special branch of economics, as well as with its implicit renditions in some of the work of other neoclassical economists. These include Marshall's implicit 'sociological economics' (Parsons 1932; Reisman 1990). Alternatively, Durkheim, Weber and other mature classical sociological theories and analyses of the economy appear as 'sociological economics', 'social economics' or 'socio-economics' from the standpoint of neoclassical and a fortiori early institutional economics (Knight 1958; Lewin 1996; Rutherford 2001). And like Mill's classical politi- 
cal economy, Marshall's and other neoclassical examples of social and sociologically minded economics look like the 'economic sociology' of capitalism in Schumpeter's (1941) sense and generally entail 'sociological elements' including those of institutionalism, from the stance of later classical sociology (Furubotn and Richter 2010; Parsons 1935). In spite of their various theoretical and methodological differences and occasional contradictions, all these figures seem to agree or converge on Comte's original and Mill's derivative classical conception and analysis of the 'social economy' and to that extent on economic sociology, which they adopt formally or substantively.

In consequence, like their precursors, later classical economic sociology and neoclassical economics share or approach a common set of fundamental concepts and assumptions. As the preceding shows, these remain essentially identical to those that early classical economic sociology and classical political economy share. Thus, the social economy in the sense of an economic system remains the basic common concept and the social, including institutional, political and cultural, constitution and conditioning of the economy the main shared assumption. For example, Durkheim ([1893] 1964, p. 158) in his economic sociology posits that commercial contracts rest on non-contractual social, notably institutional, bases on the ground that society endows a market contract with a binding power and subjects it to social regulation (so not everything in a contract is 'contractual'). More broadly, he argues that institutions and norms determine the operation and outcomes of the economy as a whole, thus expounding 'sociological institutionalism' (Boulding 1957; Parsons 1935; Merton 1998; Stinchcombe 1997; also, Rajan and Zingales 1998). Similarly, Walras's ([1896] 1936a, pp. 120-21, [1874] 1926, p. 449) rendition of 'social economy' postulates 'Good or Justice' as the 'law of moral relations of people in society'. Further, while arguing that the state is 'not an entrepreneur', he recognizes that the economy/market cannot function effectively without intervention by institutions ('some authority'), notably the state (also, Burgenmeier 1994; Perroux 1960; Sandmo 2007). To that extent, Durkheim in his economic sociology and Walras in his 'social economy' agree or converge on a normative-institutional constitution and conditioning of the economy, including market transactions, although the economic sociology is a more consistent and explicit instance of 'sociological institutionalism' than social economy.

Furthermore, and more manifestly, the mature classical idea, assumption and stage of classical economic sociology corresponds and converges with its variations in historical, original institutional and related schools of heterodox economics lying outside and going beyond classical and neoclassical orthodoxy (Furubotn and Richter 2010; Hodgson 1998). Its essential variations in these schools are the concept of historically and institutionally structured social economy and hence the assumption of institutional, political and 
cultural constitution and structuration of economic behaviors. For example, Durkheim's idea and rendition of economic sociology seems essentially compatible or convergent with the German Historical school, such as Schmoller's rendition (Rutherford 2001; also, Furubotn and Richter 2010). This hence holds even aside from Weber as this school's later nominal member to an important degree influenced by Schmoller and eventually turned sociologist (Granovetter and Swedberg 1992; Parsons [1937] 1967; Swedberg 1998). As known, Parsons ([1937] 1967, p. 12) proposes the thesis of convergence between Durkheim and Weber (along with Pareto and Marshall) on essentially a sociological theory and empirical analysis of the economy in terms of social norms and values, simply economic sociology or what Knight (1958, pp. 18-19) denotes 'sociological economics'. Furthermore, Durkheim's economic sociology displays a manifest affinity or compatibility with Veblen's ([1899] 1934), Mitchell's (1914), Commons's (1931) and other statements of original institutional economics (Boulding 1957; Davis 1945; Parsons 1935; Furubotn and Richter 2010; Hodgson 1998; Stinchcombe 1997). For example, Mitchell (1914, p. 104) suggests that one needs 'an economic sociology' to address such issues as the 'struggle between the strong and the weak' replacing 'equal opportunity for all', the 'nature and the origin of this inequality in power' and the source of the 'unity of society'. Accordingly, Schumpeter (1950, p. 144) includes or connects original institutional economics to economic sociology à la Durkheim in the sense of the 'analysis of social institutions or of "prevalent social habits", notably by implication their effects on the economy (also, Swedberg 1991). In short, they converge on what Commons (1931) calls 'institutionalism', despite some apparent differences between Durkheim's sociological and Veblen's economic theories of institutions (Parsons 1935).

Altogether, Durkheimian institutionalist sociology, the Historical school, including Weber's formulation, and Veblenian and other early institutional economics are mutually compatible or convergent. In general, they all represent in varying degrees and ways examples or proxies of economic sociology, 'sociological economics' or socio-economics as their common thread and distinct from 'pure' economics (Knight 1958; Parsons 1935). An example is the shared 'socioeconomics of Schmoller, Durkheim and Weber' (Rutherford 2001). Still, while being the most consistent, elaborate and explicit instances in this regard, they do not entirely exhaust the field in view of the noted presence of instances of 'social economics' or 'social economy' understood in the sense of a particular economic science even within neoclassical economics, as well as in classical political economy. 


\section{EARLY MODERN ECONOMIC SOCIOLOGY AND EARLY CONTEMPORARY ECONOMICS}

In essential continuation and consistency with the prior tendencies, the early modern idea, premise and phase of economic sociology corresponds and to some degree converges with its elements or approximations in early contemporary economics during the time from the 1930s to the 1980-90s. As before, early modern economic sociology especially connects and is compatible with the broader social aspect of early contemporary economics in the continuing alternative facet of 'social economics' or 'socio-economics' versus the also persisting and solidifying core of 'pure', extended neoclassical economics.

Consistent with and refining the concept of 'social economy', the conception of the economy as a constitutive component and mostly a function of society and economic action as a special case of social action undergirds and rationalizes this convergence and compatibility. In short, this represents the systems theory of the economy and society in which the first represents a subsystem of the second as the total social system, thus serving as the theoretical rationale in this respect. As implied, the systems theory of the economy and society, as well as economic and social action, begins with and underlies much of classical sociology, especially Comte, Durkheim, partly Weber and perhaps most explicitly Pareto (Fararo 2001; Parsons [1937] 1967). Early modern economic sociology, particularly Parsons and collaborators (Parsons and Smelser 1956), adopts, reformulates and elaborates the classical systems theory, and some representatives of early contemporary economics apply or imply it (Arrow 1994; Boulding 1970; Myrdal [1930] 1953).

Notably, Parsons's and related sociological systems theory of the economy as one of the subsystems of society and of economic action as one of the types of social action corresponds and occasionally converges with its variations in the works of some early contemporary economists who acknowledge that the economic system is part of the social system as a broader and more complex concept. Thus, Parsons and Smelser (1956, p. 15) restate the sociological systems theory by treating the economy as a partial 'social system' and hence as 'a sub-system of the total society'. They elaborate that as a 'social sub-system', the economy differentiates itself from other subsystems on the 'basis of functions of the society' more specifically, by performing the function of 'adaptation'. This yields the systemic definition of the economy as that 'sub-system of a society which is differentiated with primary reference to the adaptive function of the society as a whole', or simply as 'a functional sub-system of a society' (Parsons and Smelser 1956, p. 20).

Like Parsons et al. in sociology, in early postwar economics, Boulding (1970, p. 153) reformulates or approaches the systems theory by proposing 
that the economy, including the market, constitutes an integral element as well as a dependent variable of society or the 'socio-sphere' as the most complex type of system and life sphere encompassing and conditioning the economic system. Further, on the ground that pure economic models have 'very limited value' because economic processes, including development, involve the 'total society', Boulding (1970, pp. 153-5) identifies a 'whole area' that he calls 'economic sociology of the market'. Generally, Boulding (1957, p. 10) considers economic sociology one of the 'interstitial disciplines' of early contemporary economics, and some other economists during that time place it (or social economics) among 'overlapping territories' between economics and sociology (Bye 1939). Boulding (1957, pp. 4-5) especially singles out Weber, Durkheim and Pareto, as well as Simmel, as representing economic sociology and thus contributing toward the 'broadening of the outlook of economics'.

Reminiscent of both Parsons and Boulding, Arrow (1994, p. 6) applies or evokes the systems theory by considering and distinguishing 'the social system in general and the economy in particular', thus clearly implying that the former encompasses and to some degree conditions the latter, including the market, as its special component. In this systemic setting, Arrow (1994, pp. 2, 5) implies the concept of social economy and the assumption of social determination of economic action by identifying the ineradicable social element in the economy' and observing that 'individual behavior is always mediated by social relations' and tastes 'may be socially caused'. Further, Arrow (1994, pp. 1, 2) suggests that contemporary economics comprises elements or implications of economic sociology by stating that 'even the most standard economic analysis shows that social categories are in fact used in economic analysis' so that 'every economic model includes irreducibly social principles and concepts'. A case in point is the 'social concept of a market', notably markets as specific 'social institutions', reflecting the fact that even under (perfect) competition, the 'interaction of the individuals produces a social value' (Arrow 1994, p. 2).

In particular, the early modern institutionalist idea and definition of economic sociology is compatible and even essentially identical with that in early contemporary economics. Thus, Parsons's institutionalist, apparently Durkheimian conception of economic sociology complements and converges with Schumpeter's definition, which is also reminiscent of that of Durkheim. For illustration, Parsons and Smelser (1956, p. 184) advance a 'theory of institutional motivation' that while not resting on a 'theory of human nature' posits that there exist the 'basic structures of institutional motivation' that are acquired in the 'course of social experience'. In particular, it postulates that the 'internalization of culture patterns in social situations' forms in the personality the 'motivational counterpart' of the 'institutionalization of the same patterns of the social system'. Especially, the theory postulates an 'appropriate institu- 
tionalized and internalized value system of the economy' of which individual economic rationality is a 'function' (Parsons and Smelser 1956, p. 185).

In turn, Schumpeter (1954, p. 9) redefines economic sociology as the 'analysis of social institutions' and their effects on the economy versus pure economics as the 'study of economic mechanisms', which evidently follows on or echoes Durkheim's institutionalist definition noted above. Further, Schumpeter (1951, p. 287) provides another similar institutional definition of economic sociology with apparent reference to or an echo of Weber and in part Veblen: the 'description and interpretation - or interpretative description - of economically relevant institutions, including habits and all forms of behavior in general, such as government, property, private enterprise, customary or "rational" behavior.' In addition, Schumpeter (1956, p. 287) depicts economic sociology as 'no man's land or everyman's land' developing out of the inevitable overlap of the shared concerns of economists and sociologists with social institutions and thus the forces shaping economic behavior. More specifically, Myrdal ([1930] 1953, p. 97) centers on 'institutional factors' determining the 'structure of the market, even the whole economic system', and proposes that social forces having 'enough political power' can radically change institutional factors in a group's own interest. Relatedly, Keynes ([1936] 1960, p. 329), evoking both Marshall's latent (and Mill's) and Durkheim's manifest institutionalism, registers with regret that 'all kinds of social customs and economic practices' perpetuate the 'distribution of wealth and of economic rewards and penalties useful in promoting the accumulation of capital', while hoping these influences will be discarded in the future. In this sense, the institutionalist formulation of economic sociology primarily connects the latter in its early modern stage and early contemporary sociologically minded economics in their respective Parsons's and Schumpeter's/Myrdal's versions and Keynes's ramifications.

More broadly, the formal status of early modern economic sociology within sociology corresponds to that of it in sections of early contemporary economics, as Parsons's and Schumpeter's and Boulding's versions show. Thus, the prominent place of economic sociology involving the analysis of the economy and society within Parsons's and related sociological theory compares with its position as a legitimate branch of economics in Schumpeter's, Boulding's and cognitive economic theories. Schumpeter (1954, pp. 9-22) incorporates economic sociology into 'economic analysis', together with economic theory, as well as economic history and other branches, which therefore makes his rendition of economics virtually identical to Weber's 'social economics' also involving the first three fields. Similarly, Boulding (1957, p. 10) proposes including economic sociology into the 'interstitial disciplines' of contemporary economics, along with political economy, economic psychology and economic anthropology, with their 'spectrum of theoretical structures'. By 
doing so Schumpeter and Boulding continue and elaborate on Jevons's explicit incorporation and elevation of economic sociology to one of the subdivisions and rescuers of economic science. Further, their contemporary Myrdal ([1930] 1953, p. 204) treats what he names the 'technology of economics' as a 'branch of the modern psychologically orientated sociology'.

In particular, the idea of the sociology of the market as a subdivision of economic sociology self-evidently converges with, and even seemingly overlaps with, its formulation or approximation in segments of early contemporary economics. Thus, applying the systems theory of the economy and society, Parsons and Smelser (1956, p. 174) propose a sociological conception of the market that considers the latter a specific 'social system' with various social-systemic (i.e., goal-attainment, adaptive, integrative and value) 'components'. In particular, this conception treats market structures as differing in 'sociological type, not merely along some dimension of competitiveness' (Parsons and Smelser 1956, p. 173). Equally, in early contemporary economics, as seen, Boulding (1970, pp. 153-5) identifies and advocates 'economic sociology of the market'. As noted, Boulding (1970, pp. 153-5) does this on the ground that the market, as the economy overall, implicates and depends on the 'total society' or the 'socio-sphere', and because of the resulting 'very limited value' of the 'purely economic models'. In turn, Parsons's treatment of market structures as differing in extra-economic 'sociological type' complements or coincides with Chamberlin's (1951, p. 135) proposition that many market situations, including monopoly, oligopoly and monopolistic competition, are 'indeterminate' only when taking account of the 'economic variables involved' and yet become 'determinate only by the influence of non-economic factors'. Moreover, Myrdal ([1930] 1953, p. 100) suggests that the sociology of the market, including social psychology, can produce 'more satisfying results' than economics in explaining the 'causes of supply, demand and prices'. Relatedly, Keynes ([1936] 1960, p. 155) identifies a variation on social psychology à la Durkheim or Le Bon in the form of the 'mass psychology of the market'. The latter consists in that the it is driven, especially in 'abnormal times', by 'waves of optimistic and pessimistic sentiment' expressing 'animal spirits' that are hence to some extent socially conditioned or diffused and represent social-psychological rather than, as most later economists construe them, purely innate, natural forces (also, Akerlof and Shiller 2009; Phelps 2007).

The preceding holds for various other subdivisions of early modern economic sociology. For instance, the idea and status of sociology of economic organizations within early modern, especially Parsonian, sociological theory converges or coincides with and complements that of the 'sociology of enterprise' in Schumpeter's economics framework. Parsons's sociological conception of economic and other organizations treats these as "part of the structure 
of the society', while endowing 'business firms' with 'economic primacy', even though he does not consider them (the whole of) the 'economy' (Parsons 1951, p. 175; Parsons and Smelser 1956, p. 61). Similarly, Schumpeter (1951, pp. 224-5), apparently following Weber's sociological analysis of entrepreneurship in the context of the spirit of capitalism, outlines the 'sociology of enterprise', investigating the 'conditions that produce and shape, favor or inhibit entrepreneurial activity' and classifying entrepreneurs according to social origins and 'sociological types', even extending to the 'structure and the very foundations of capitalist society'. In turn, Arrow (1994, pp. 2-4) affirms that business firms are 'organizations, not individuals' and thus by implication 'social categories' by virtue of having an 'ineradicable social element'.

In consequence of the above, just as do their antecedents, early modern economic sociology and early contemporary economics share a set of common concepts or theories and premises or assumptions. In sum, the basic conception they share becomes the systems theory of the economy and society, and of economic and social action, either in an explicit formulation as in sociology or in more implicit versions as in economics, formalizing and refining the concept of 'social economy' as a subsystem and function of the total social system. In turn, the main shared assumption continues to be the social, notably institutional, constitution and determination of the economy, particularly the market, which economic sociology of the market assumes and emphasizes.

\section{LATER MODERN ECONOMIC SOCIOLOGY AND CURRENT ECONOMICS}

Finally, the modern framework and stage of economic sociology also corresponds and to a large extent converges with its current elements or implications in economics. Thus, the concepts and principles of a systematic sociological analysis of the economy as a whole and the market in particular in modern (or the new) economic sociology relate and are essentially compatible with the growing adoption and incorporation of sociological and similar assumptions and concepts in sections of current, especially social, institutional, political and in part behavioral, economics. (See Fligstein 2001; Granovetter 2017; Smelser and Swedberg 2005, Swedberg 2003 in sociology; Acemoglu 2010; Akerlof 2002; Akerlof and Shiller 2009; Becker and Murphy 2000; North 2005; Piketty 2014; Thaler 2018; Williamson 2000 in economics.)

For illustration, leading contemporary sociologically minded economists such as, especially, Akerlof (2002, p. 411) and others introduce and emphasize certain sociological and related factors, for example 'cognitive bias, reciprocity, fairness, herding, and social status', into conventional economic analysis. (See also Akerlof and Shiller 2009; Benabou and Tirole 2011; Bowles and Gintis 2000; Cappelen et al. 2007; Henrich et al. 2001; Hodgson 1994; Konow 
2000; Phelps 2007; Sen 1999.) Despite some resistance or dismissal by its 'purist' exponents, even parts of mainstream economic analysis and theory consequently acquire important elements or approximations of economic sociology and thus move toward or approach 'sociological economics' (Akerlof 1997; Collins 1986; Gibbons 2005; Lewin 1996; Piore 2002; Solow 1990).

In this context, for example, social and behavioral economics incorporates 'realistic assumptions' founded on sociological and related observations and particularly recognizes that institutions operate as 'a major determinant of market structure' (Akerlof 2002, pp. 412-13; also, Fershtman, Gneezy and List 2012; Bowles and Gintis 2000; Hodgson 1998; Thaler 2018). A case in point are 'sociological explanations for efficiency wages', including the 'sociological version of efficiency wage theory based on gift exchange', that are indeed deemed 'empirically most convincing' compared to their purely economic alternatives (Akerlof 2002, pp. 412-13; also, Goldschmidt and Schmieder 2017; MacLeod and Malcomson 1998; Sen 1994). Another example consists of sociological and similar models, including the 'insider-outsider model', of involuntary unemployment incorporating elements beyond standard economics and yet likely yielding 'a better overall explanation' (Akerlof 2002, pp. 415-16).

An additional case in this setting is the sociological model of consumption in which, by contrast to neoclassical economics' life-cycle model, a 'major determinant of consumption' are social norms that define what goods different social groups (think they) should consume, considered either entitlements or obligations. (See Akerlof 2007, p. 15; also, Ball et al. 2001; Becker and Murphy 2000; Immorlica et al. 2017.) This process includes the 'consumption of cultural goods' determined by class factors, invoking Bourdieu's (1984) sociological theory of artistic consumption driven by the quest of social distinction in that the upper class refrains from making 'lower-class choices' in aesthetic culture while the opposite pattern holds for lower classes (Akerlof 2007, p. 15; also, Aspers and Godart 2013; Kranton 2016). A further example represents the 'sociology of the corporation' as a subfield of economic sociology that considers the 'norms of corporate decision makers' to be major forces and treats firms as social, 'governance structures rather than production functions' (Akerlof 2007, p. 20; Williamson 1998, p. 77; also, Akerlof and Shiller 2009; Coase 1998; Hodgson 1994; Stiglitz 2002). A related instance involves the sociological model of entrepreneurship that is premised on the new economic sociology's concept of social connections and networks (also termed 'social capital') among entrepreneurs and other economic actors, and evokes Weber-Schumpeter's sociology of enterprise and capitalist development. (See Akerlof and Holden 2016; also, Blume et al. 2015; Kerr, Nanda and Rhodes-Kropf 2014; McCleary and Barro 2006; Sobel 2002; Spolaore and Wacziarg 2013.) 
The tendency toward introducing sociological assumptions and factors into economic analysis effectively reintroduces modern economic sociology into current economics as its special branch or an intermediate discipline between economics and sociology in the manner reminiscent of Jevons, Schumpeter, Boulding and other earlier economists. Moreover, the semi-official result is formally classifying economic sociology into the fields or categories of modern economics, for example under category Z13 'Economic Sociology' (along with 'Economic Anthropology', as well as 'Social and Economic Stratification') in the Journal of Economic Literature (JEL) classification system. Consequently, economic sociology becomes a branch of modern sociology and current economics alike - a kind of Schumpeter's 'everyman's land' spanning both disciplines. It thus facilitate their rapprochement and possibly a degree of integration or combination emulating that existing since Comte and J. S. Mill through Jevons and Pareto to Parsons and Schumpeter, mostly before the 1930s, along with some postwar cases prior to the ascendance of the ostensibly 'universal approach to human behavior'. Moreover, economic sociology primarily and crucially contributes to such rapprochement and possible reintegration or renewed affinity between modern sociology and sections of current economics, in contrast to or apart from the 'economic approach to human behavior' or 'rational choice' theory that seems to manifest less this symmetrical tendency than what Boulding (1969) deplores as asymmetrical 'economic(s) imperialism'.

More broadly, modern economic sociology especially complements and converges with contemporary social economics as a branch or trend in some segments of contemporary economic science (Granovetter and Swedberg 1992). Thus, the revival and reaffirmation of economic sociology within modern sociological analysis corresponds and is generally compatible with the reemergence and rehabilitation of social economics or socio-economics in parts of contemporary economic theory (Smelser and Swedberg 2005). Like modern economic sociology, contemporary social economics is considered a broader alternative or complement to pure and narrow neoclassical economics (Blume et al. 2015; Lutz 1990; O’Boyle 1996; also, Becker and Murphy 2000).

Furthermore, this modern state of economic sociology essentially overlaps with that of what some prominent contemporary economists propose as 'sociological economics', which they consider a proper branch and indeed the essence of economics as social science on the ground of social, including especially institutional, context and determination of the economy and market (Collins 1986; Hodgson 2000; Lewin 1996; Solow 1990). For instance, Solow (1990, p. 282) disagrees with the 'notion of economics as physics' in favor of that as 'sociological economics' because economics is a 'social science'. Notably, Solow (1990, p. 277) empirically grounds 'sociological economics' 
in stating that all economic activity is 'embedded in a web of social institutions, customs, beliefs, and attitudes'. Similarly, Lewin (1996, p. 1305) pleads for 'sociological economics' or 'sociologically complex economics' not limiting its attention to 'market phenomena' but extending it into their institutional and social factors. Hence, the empirical rationale for 'sociological economics' consists in that 'sociological influences deeply affect the psychology underlying economic behavior' which necessitates taking account of the 'social forces that influence human decision making', consistent with that 'economics is a social science, and that institutional and social issues are what really count' (Lewin 1996, pp. 1305, 1320). ${ }^{5}$ In addition, Hodgson (2000) proposes 'sociological economics' as 'a more accurate and better term' so long as economics is the 'study of the economy' and considers Coase's (1998) redefinition of economics in terms of an analysis of 'social institutions' to be 'very close to Durkheim's and Schumpeter's respective definitions of sociology in general and of economic sociology'. In this connection, Hodgson (2000) restates Comte-Durkheim-Pareto-Parsons's sociological systems theory of the economy and society by characterizing the economy as that 'large part of the social system devoted to the production and distribution of goods and services'. In addition, leading contemporary sociologists like Collins (1986, p. 1352), while characterizing the rational choice model as 'an imperialist intrusion' from the most 'backward' areas of economics into sociology, predict that reconstructed economics will be 'sociological economics'. Alternatively, 'sociological economics' becomes economics' equivalent or analogue to economic sociology, as Knight (1958), among earlier contemporary economists, suggests by using the term with reference to Weber-Sombart's broadening of the later Historical school, and as corresponding to Durkheim's 'economic sociology' (see also Weiller and Homme 1958). ${ }^{6}$

To that extent sociology and economics remain closely related disciplines, allied social sciences primarily through modern economic sociology and contemporary social or sociological economics, respectively, just as they have been since Comte and Mill through Durkheim, Pareto and Walras to Parsons and Schumpeter and other later sociologists and economists. Even if the two are not completely identical, modern economic sociology and contemporary social economics parallel and connect with each other by both representing the theory and analysis of economic behavior as a special case of social action and the economy as a part and function of society, including its institutional structure, political system and culture. In short, they both theorize and analyze a social economy and its societal, especially institutional, constitution and determination. In this regard, the analytical framework and principles of modern (i.e., new) economic sociology intersect and converge with those of contemporary social or sociological economics (Blume et al. 2015; Granovetter 2017; Hodgson 2000; Smelser and Swedberg 2005). 
In consequence, the later modern rendition and stage of economic sociology shares or approximates a common set of basic concepts and of main assumptions with its current variations or approximations in economics. As implied, the basic shared concept continues to be that of social economy either in its conventional formulations à la Comte/Durkheim in sociology and Say/Mill in economics or in its modern reformulations. Thus, both modern economic sociology and contemporary sociologically minded or social economics share the classical and later concept of social economy as an economic system of society and hence the subsystem of the total social system (Granovetter 2017; Lutz 1990; Phelps 2007; Smelser and Swedberg 2005). They also share its modern reformulations such as the concept of a socially embedded economy or economic action, which the new economic sociology reinvents and reaffirms and sociological, including especially institutional, economics implies and adopts (Granovetter 1985; Healy and Krawiec 2017; Hodgson 1998; Jackson, Rodriguez-Barraquer and Tan 2012; Solow 1990). In retrospect, the new economic sociology's concept of a socially embedded economy is already implicit in Comte's classical sociological statement that the social economy with its 'various functions' is 'naturally implicated' in social relations, as well as some anthropological observations that in earlier societies the human economy is 'embedded and enmeshed' in economic and non-economic institutions (Polanyi 1958). As it stands, just as that of social economy leading to or entailing the premise of its societal constitution and determination, this concept leads to or entails the assumption of 'social embeddedness of the economy' stating the degree to which non-economic actions and institutions affect or link with economic action (Granovetter 2005). In sum, social economy remains, or socially embedded economic behavior in terms of social connections, networks and institutions becomes, the major concept that modern economic sociology and its variations in economics, especially contemporary sociologically minded or social economics, explicitly or by implication share.

Equally, and as a corollary, the main shared premise or assumption of modern economic sociology and of its current elements or implications in economics remains the social, in particular institutional, political and cultural, constitution and determination of the economy and market in either conventional formulations noted previously or recent reformulations. Thus, modern economic sociology and contemporary sociological or social economics alike share the classical and later principle of societal, including institutional, political and cultural, framework and conditioning of the economy in general and the market in particular and their outcomes (Acemoglu 2010; Akerlof 2002; Fligstein 2001; Granovetter 2017; Piketty 2014; Smelser and Swedberg 2005). In addition, as implied, they share some recent reformulations of this principle, especially the assumption of the social embeddedness and structuring of economic actors and activities that modern economic sociology restates and 
refines and contemporary sociological or social, including institutional, economics embraces or implies. (See Granovetter 2005; Healy and Krawiec 2017; Jackson, Rodriguez-Barraquer and Tan 2012; Solow 1990; Williamson 2000; also, Callon 1998.) In turn, as expected, this assumption elaborates on the implicit premise of social embeddedness in classical economic sociology since Comte's proposition of social relations embedding or implicating economic processes and refines and extends Polanyi's explicit formulation in economic anthropology from early non-market to contemporary market economies.

Moreover, sections of modern economics such as some versions of the 'new' institutional economics explicitly adopt and reformulate the 'condition of societal embeddedness' as one of their 'background conditions' (Williamson 1998; also, Gagnon and Goyal 2017). In this institutional reformulation, the social embeddedness condition antedates the polity and pertains to 'societal features' such as norms, customs, mores, traditions and religion varying among groups and nation states and operating as 'societal supports, or the lack thereof, for credible contracting' (Williamson 1998, p. 78; 2000, p. 596). Accordingly, the 'social embeddedness level' involving these factors becomes the 'top level' of the analysis of institutions in this context. In addition, some models of entrepreneurship in contemporary economics incorporate 'theoretical perspectives' from the new economic sociology, such as the social embeddedness conception that entrepreneurs and other economic actors exploit their 'network position' (Akerlof and Holden 2016). More broadly, other contemporary economists emphasize the role of social networks in economic behaviors and thus the 'embeddedness of many economic transactions', warning against 'abstracting from social structure' because the latter helps better understanding these 'behaviors and their causes' (Jackson, Rogers and Zenou 2017).

Overall, while not completely new with respect to both classical sociology and economic anthropology (with Polanyi as the recognized early inventor), the social embeddedness assumption acquires the status of a proxy shared paradigm or analytical level in modern economic sociology explicitly and in its variations or approximations in economics such as contemporary social economics mostly by implication. (See Granovetter 2005; Fourcade and Healy 2007; Jackson 2014; Williamson 2000.) Further, its place in modern economics includes, among other things, the explicit status of social embeddedness as a 'background condition' and the 'top level' of analysis in sections of the new institutional economics, the incorporation of network positions in some models of entrepreneurship, and generally the salience of social networks in analyses of economic behaviors. 


\section{CONCLUSION}

If sociology and economics are 'sister disciplines' or allied social sciences, this is primarily because of their common and thus symmetrical tendency toward economic sociology - which is what Schumpeter suggests by depicting the latter as 'everyman's land' to be cultivated across the two fields - and just secondarily of other tendencies, especially those being asymmetrical or imperial in theoretical and methodological terms. In passing, in contrast to that toward economic sociology, these other tendencies include the expansion of rational choice theory or the comprehensive economic approach to human behavior as instead an asymmetrical, one-sided movement expressing 'economic imperialism' or neoclassical economics' attempt at 'colonization' of sociology and the other social sciences, especially political science. Moreover, some leading contemporary economists admonish that '[i]ndeed the uncritical acceptance of the rationality assumption is devastating for most of the major issues confronting social scientists and is a major stumbling block in the path of future progress' (North 2005, p. 4; also, Hodgson 1998; Piore 2002; Williamson 2000). On this account, compared to rational choice theory, economic sociology or sociologically minded economics appears as a comparatively more efficacious and faster path of joint progress in modern sociology and current economics (Akerlof 2002; Collins 1986; Granovetter 2005; Lewin 1996; Solow 1990).

In general, the principal ideas, premises and stages of economic sociology as a multidisciplinary field of both sociology and economics correspond, converge and are essentially compatible with its elements, variations and implications in economics. This holds for the four main types and stages of economic sociology - early classical, mature classical, early modern and later modern - in relation to its elements in the corresponding versions and phases of economics - classical, neoclassical, early and later contemporary. In particular, later modern economic sociology connects and converges with its variations and designations in contemporary economics (e.g., 'economic sociology' in the JEL classification system). In addition, it parallels its equivalents and analogues in contemporary economics such as sociological economics, socio-economics, social economics or social economy. Accordingly, both modern economic sociology and its variations and approximations in economics continue to share or approach a common set of concepts and assumptions. More specifically, this set comprises the concept of social economy or socially embedded economy as a constitutive component of society and the subsystem of the total social system. Relatedly, it involves the assumption of social, including political, institutional and cultural, constitution and determination of the economy, including its reformulation through the conception of social 
embeddedness and structuring of economic actors and actions, as the proxy shared modern paradigm.

Finally, what follows are the specific contributions to the Modern Guide to Economic Sociology from both economists and sociologists working in this interdisciplinary field. The ensuing contributions to the guide in a way speak for themselves and do not need a summary and elaboration. Moreover, such a description probably would not do full justice to them and would perhaps deprive the reader of the pleasure of reading them as they stand. Therefore, the reader is invited to proceed next by reading these valuable contributions to the expanding field of economic sociology in both contemporary sociology and contemporary economics.

\section{NOTES}

1. Bladen (1941, p. 18) comments that 'Mill, when he came to write his Principles, abandoned his ambition to work out a purely abstract theory and adopted a broader view of the scope and method of political economy under the influence of Comte.'

2. Schumpeter (1954, p. 416) notes that Comte 'introduced into the social sciences the concepts of statics and dynamics', as does Hayek (1950, pp. 17-18), who, however, finds it 'questionable whether the introduction of the terms statics and dynamics into economics (by John Stuart Mill following Comte's similar division in sociology) ... was beneficial.'

3. Granovetter and Swedberg (1992, p. 4) conclude that on the balance 'Weber's ideas were ultimately closer to those of Comte and the Historical School than to those of the other side', namely Ricardo, Menger and generally Austrian economics.

4. Lie (1997, p. 354) cites and estimates that 'Wicksteed's conclusion remains relevant today', adding that the 'study of markets is too important to be left to economists'.

5. Lewin (1996, pp. 1294-5) adds that 'any serious reevaluation of the psychological underpinning of economics requires that careful attention be paid to sociological analyses' and that the 'sociological shortcomings [of economics] are much more fundamental and difficult to address' than are the psychological.

6. Weiller and Homme (1958, p. 377) state that sometimes the movement from economics to sociology 'can be directed towards the extension of economic explorations, which in this case more or less coincide with sociological preoccupations: it then tends towards some kind of sociological economics (where more or less are superimposed the fields of the two disciplines, and in all cases approached by their methods). But it can also lead to the creation of economic sociology: this discipline stands alongside the economic analysis - which maintained its autonomy - and explores the vast domain that economic analysis has definitely abandoned.'

\section{REFERENCES}

Acemoglu, D. (2010), 'Institutions, factor prices, and taxation: Virtues of strong states?', American Economic Review, 100 (2), 115-19. 
Akerlof, G. (1997), 'Social distance and social decisions', Econometrica, 65 (5), $1005-28$.

Akerlof, G. (2002), 'Behavioral macroeconomics and macroeconomic behavior', American Economic Review, 92 (3), 411-33.

Akerlof, G. (2007), 'The missing motivation in macroeconomics', American Economic Review, 97 (1), 5-36.

Akerlof, George and Robert Shiller (2009), Animal Spirits, Princeton: Princeton University Press.

Akerlof, R. and R. Holden (2016), 'Movers and shakers', Quarterly Journal of Economics, 131 (4), 1849-74.

Arrow, K. (1994), 'Methodological individualism and social knowledge', American Economic Review, 84 (2), 1-9.

Aspers, P. and F. Godart (2013), 'Sociology of fashion: Order and change', Annual Review of Sociology, 39, 171-92.

Backhouse, R. (2015), 'Revisiting Samuelson's Foundations of Economic Analysis', Journal of Economic Literature, 53 (2), 326-50.

Ball, S., C. Eckel, P. Grossman and W. Zame (2001), 'Status in markets', Quarterly Journal of Economics, 116 (1), 161-88.

Becker, Gary and Kevin M. Murphy (2000), Social Economics, Cambridge, Mass.: Harvard University Press.

Benabou, R. and J. Tirole (2011), 'Identity, morals, and taboos: Beliefs as assets', Quarterly Journal of Economics, 126 (2), 805-55.

Bladen, V. (1941), 'Mill to Marshall: The conversion of the economists', Journal of Economic History, 1 (S1), 17-29.

Blume, L., W. Brock, S. Durlauf and R. Jayaraman (2015), 'Linear social interactions models', Journal of Political Economy, 123 (2), 444-96.

Boulding, K. (1957), ‘A new look at institutionalism', American Economic Review, 47 (2), $1-12$.

Boulding, K. (1969), 'Economics as a moral science', American Economic Review, 59 (1), $1-12$.

Boulding, Kenneth (1970), Economics as a Science, New York: McGraw-Hill.

Bourdieu, Pierre (1984), Distinction: A Social Critique of the Judgement of Taste, Cambridge, Mass.: Harvard University Press.

Bowles, S. and H. Gintis (2000), 'Walrasian economics in retrospect', Quarterly Journal of Economics, 115 (4), 1411-39.

Burgenmeier, B. (1994), 'The misperception of Walras', American Economic Review, $84(1), 342-52$.

Bye, R. (1939), 'The scope and definition of economics', Journal of Political Economy, 47 (5), 623-47.

Cairnes, John (1874), Some Leading Principles of Political Economy, reprinted (1967), New York: A. M. Kelley.

Callon, Michel (1998), 'Introduction: The embeddedness of economic markets in economics', in Michel Callon (ed.), The Laws of the Markets, Oxford: Blackwell Publishers, pp. 1-57.

Cappelen, A., A. Hole, E. Sørensen and B. Tungodden (2007), 'The pluralism of fairness ideals: An experimental approach', American Economic Review, 97 (3), 818-27.

Cassel, Gustav (1929), Traité D'économie Politique, Paris: Marcel Girard.

Chamberlin, E. (1951), 'The impact of recent monopoly theory on the Schumpeterian system', Review of Economics and Statistics, 33 (2), 133-8. 
Clark, J. B. (1899), 'Natural divisions in economic theory', Quarterly Journal of Economics, 13 (2), 187-203.

Coase, R. (1978), 'Economics and contiguous disciplines', Journal of Legal Studies, 7 (2), 201-11.

Coase, R. (1998), 'The new institutional economics', American Economic Review, 88 (2), 72-4.

Collins, R. (1986), 'Is 1980s sociology in the doldrums?', American Journal of Sociology, 91 (6), 1336-55.

Commons, J. (1931), 'Institutional economics', American Economic Review, 21 (4), $648-57$.

Comte, Auguste (1839), Auguste Comte and Positivism: The Essential Writings, reprinted (1983), Chicago: University of Chicago Press.

Davis, A. (1945), 'Sociological elements in Veblen's economic theory', Journal of Political Economy, 53 (2), 132-49.

Durkheim, Emile (1893), The Division of Labor in Society, reprinted (1964), New York: The Free Press.

Durkheim, Emile (1895), The Rules of Sociological Method and Selected Texts on Sociology and Its Method, reprinted (1982), New York: The Free Press.

Durkheim, Emile (1909), Emile Durkheim on Institutional Analysis, reprinted (1994), Chicago: University of Chicago Press.

Durkheim, Emile (1912), Elementary Forms of Religious Life, reprinted (1976), London: Allen and Unwin.

Edgeworth, Francis (1881), Mathematical Psychics: An Essay in the Application of Mathematics to the Moral Sciences, reprinted (1967), New York: A. M. Kelley.

Fararo, Thomas (2001), Social Action Systems: Foundation and Synthesis in Sociological Theory, Westport: Praeger.

Fershtman, C., U. Gneezy and J. List (2012), 'Equity aversion: Social norms and the desire to be ahead', American Economic Journal: Microeconomics, 4 (4), 131-44.

Fligstein, Neil (2001), The Architecture of Markets: An Economic Sociology of 21st Century Capitalist Societies, Princeton: Princeton University Press.

Forget, Evelyn (1999), The Social Economics of Jean-Baptiste Say: Markets and Virtues, London: Routledge.

Fourcade, M. and K. Healy (2007), 'Moral views of market society', Annual Review of Sociology, 33, 285-311.

Furubotn, Eirik and Rudolf Richter (2010), Institutions and Economic Theory: The Contribution of the New Institutional Economics, Ann Arbor: University of Michigan Press.

Gagnon, J. and S. Goyal (2017), 'Networks, markets, and inequality', American Economic Review, 107 (1), 1-30.

Gibbons, R. (2005), 'What is economic sociology and should any economists care?', Journal of Economic Perspectives, 19 (1), 3-7.

Goldschmidt, D. and J. F. Schmieder (2017), 'The rise of domestic outsourcing and the evolution of the German wage structure', Quarterly Journal of Economics, 132 (3), $1165-217$.

Granovetter, M. (1985), 'Economic action and social structure: The problem of embeddedness', American Journal of Sociology, 91 (3), 481-510.

Granovetter, M. (2005), 'The impact of social structure on economic outcomes', Journal of Economic Perspectives, 19 (1), 33-50.

Granovetter, Mark (2017), Society and Economy: Framework and Principles, Cambridge, Mass.: Harvard University Press. 
Granovetter, Mark and Richard Swedberg (1992), 'Introduction', in Mark Granovetter and Richard Swedberg (eds), The Sociology of Economic Life, Boulder: Westview Press, pp. 1-26.

Hamilton, Gary and Robert Feenstra (1998), 'The organization of economies', in Mary Brinton and Victor Nee (eds), The New Institutionalism in Sociology, New York: Russell Sage Foundation, pp. 153-80.

Hayek, Friedrich (1950), The Pure Theory of Capital, Chicago: University of Chicago Press.

Healy, K. and K. Krawiec (2017), 'Repugnance management and transactions in the body', American Economic Review, 107 (5), 86-90.

Henrich, J., R. Boyd, S. Bowles, C. Camerer, E. Fehr, H. Ginitis and R. McElreath (2001), 'In search of Homo Economicus: Behavioral experiments in 15 small-scale societies', American Economic Review, 91 (2), 73-8.

Hodgson, G. (1994), 'The return of institutional economics', in Neil Smelser and Richard Swedberg (eds), Handbook of Economic Sociology, Princeton: Princeton University Press, pp. 58-76.

Hodgson, G. (1998), 'The approach of institutional economics', Journal of Economic Literature, 36 (1), 166-92.

Hodgson, G. (2000), 'Economic sociology - or econology?', Economic Sociology Editorial Series, accessed at http:/www.sociosite.net/topics/econsoc.php.

Immorlica, N., R. Kranton, M. Manea and G. Stoddard (2017), 'Social status in networks', American Economic Journal: Microeconomics, 9 (1), 1-30.

Jackson, M. (2014), 'Networks in the understanding of economic behaviors', Journal of Economic Perspectives, 28 (4), 3-22.

Jackson, M., T. Rodriguez-Barraquer and X. Tan (2012), 'Social capital and social quilts: Network patterns of favor exchange', American Economic Review, 102 (5), 1857-97.

Jackson, M., B. Rogers and Y. Zenou (2017), 'The economic consequences of social-network structure', Journal of Economic Literature, 55 (1), 49-95.

Jevons, William S. (1879), The Theory of Political Economy, reprinted (1965), New York: A. M. Kelley.

Kerr, W., R. Nanda and M. Rhodes-Kropf (2014), 'Entrepreneurship as experimentation', Journal of Economic Perspectives, 28 (3), 25-48.

Keynes, John M. (1936), The General Theory of Employment, Interest and Money, reprinted (1960), London: Macmillan.

Keynes, John N. (1890), The Scope and Method of Political Economy, reprinted (1955), New York: Kelley and Millman.

Knight, Frank (1958), On History and Method of Economics, Chicago: University of Chicago Press.

Konow, J. (2000), 'Fair shares: Accountability and cognitive dissonance in allocation decisions', American Economic Review, 90 (4), 1072-92.

Kranton, R. (2016), 'Identity economics: Where do social distinctions and norms come from?', American Economic Review, 106 (5), 405-9.

Lawson, Tony (1997), Economics and Reality, London: Routledge.

Lewin, S. (1996), 'Economics and psychology: Lessons for our own day from the early twentieth century', Journal of Economic Literature, 34 (3), 1293-324.

Lie, J. (1997), 'Sociology of markets: Heterogeneity, power and macrosociological foundations', Annual Review of Sociology, 23, 341-60.

Lutz, Mark (ed.) (1990), Social Economics, Boston: Kluwer Academic Publishers. 
MacDonald, R. (1965), 'Schumpeter's and Weber's central visions and social theories', Quarterly Journal of Economics, 79 (3), 373-96.

MacLeod, B. and J. Malcomson (1998), 'Motivation and markets', American Economic Review, 88 (3), 388-411.

Marshall, Alfred (1891), Principles of Economics, reprinted(1961), London: Macmillan.

Marx, Karl (1859), A Contribution to the Critique of Political Economy, reprinted (1970), New York: International Publishers.

McCleary, R. and R. Barro (2006), 'Religion and economy', Journal of Economic Perspectives, 20 (2), 49-72.

Merton, R. (1998), 'Foreword', in Mary Brinton and Victor Nee (eds), The New Institutionalism in Sociology, New York: Russel Sage Foundation, pp. xi-xiii.

Mill, John S. (1874), Essays on Some Unsettled Questions of Political Economy, reprinted (1974), New York: A. M. Kelley.

Mitchell, Wesley C. (1917), 'Wieser's theory of social economics', Political Science Quarterly, 32 (1), 95-118.

Myrdal, Gunnar (1930), The Political Element in Development of Economic Theory, reprinted (1953), London: Routledge and Kegan Paul.

North, C. (1915), 'The sociological implications of Ricardo's economics', American Journal of Sociology, 20 (6), 764-828.

North, D. (2005), Understanding the Process of Economic Change, Princeton: Princeton University Press.

O’Boyle, Edward (ed.) (1996), Social Economics, London: Routledge.

Pareto, Vilfredo (1909), Manuel D'économie Politique, reprinted (1927), Paris: Marcel Girard.

Pareto, Vilfredo (1916), Traité De Sociologie Generale, reprinted (1932), Paris: Payot.

Parsons, T. (1932), 'Economics and sociology: Marshall in relation to the thought of his time', Quarterly Journal of Economics, 46 (2), 316-47.

Parsons, T. (1935), 'Sociological elements in economic thought', Quarterly Journal of Economics, 49 (3), 414-53.

Parsons, Talcott (1937), The Structure of Social Action, reprinted (1967), New York: The Free Press.

Parsons, Talcott (1951), The Social System, New York: The Free Press.

Parsons, Talcott and Neil Smelser (1956), Economy and Society: A Study in the Integration of Economic and Social Theory, New York: The Free Press.

Perroux, Francois (1960), Economie et Société, Paris: P.U.F.

Phelps, E. (2007), 'Macroeconomics for a modern economy', American Economic Review, 97 (3), 543-61.

Piketty, Thomas (2014), Capital in the Twenty-First Century, Cambridge, Mass.: Harvard University Press.

Piore, M. (2002), 'Economics and sociology', Revue économique, 53 (2), 291-300.

Polanyi, Karl (1958), 'The economy as instituted process', in Karl Polanyi, Conrad Arensberg and Harry Pearson (eds), The Early Empires, New York: The Free Press, pp. 122-43.

Rajan, R. and L. Zingales (1998), 'Power in a theory of the firm', Quarterly Journal of Economics, 111 (3), 387-428.

Reisman, David (1987), Adam Smith's Sociological Economics, London: Macmillan.

Reisman, David (1990), Alfred Marshall's Mission, New York: St. Martin's Press.

Ricardo, David (1846), The Works of David Ricardo, reprinted (2010), J. R. McCulloch (ed.), Indianapolis: Online Library of Liberty. 
Robbins, L. (1981), 'Economics and political economy', American Economic Review, 71 (2), 1-10.

Rutherford, M. (2001), 'Institutional economics: Then and now', Journal of Economic Perspectives, 15 (3), 173-94.

Samuelson, Paul (1983), Foundations of Economic Analysis, Cambridge, Mass.: Harvard University Press.

Samuelson, Paul (1994), 'The classical classical fallacy', Journal of Economic Literature, 32 (2), 620-39.

Sandmo, A. (2007), 'Leon Walras and the Nobel peace prize', Journal of Economic Perspectives, 21 (4), 217-28.

Say, Jean-Baptiste (1828), Cours Complet D'economie Politique Practique: L'Economies Des Societes, reprinted (1852), Paris: Rapilly.

Schumpeter, J. (1941), 'Alfred Marshall's Principles: A semi-centennial appraisal', American Economic Review, 31 (2), 236-48.

Schumpeter, J. (1911), The Theory of Economic Development, reprinted (1949a), Cambridge, Mass.: Harvard University Press.

Schumpeter, J. (1949b), 'The Communist Manifesto in sociology and economics', Journal of Political Economy, 57 (3), 199-212.

Schumpeter, J. (1950), 'Wesley Clair Mitchell (1874-1948)', Quarterly Journal of Economics, 64 (1), 139-55.

Schumpeter, Joseph (1951), Essays on Economic Topics, Port Washington: Kennikat Press.

Schumpeter, Joseph (1954), History of Economic Analysis, New York: Oxford University Press.

Schumpeter, Joseph (1956), Ten Great Economists, London: Allen and Unwin.

Sen, Amartya (1994), 'The formulation of rational choice', American Economic Review, 84 (2), 385-90.

Sen, Amartya (1999), 'The possibility of social choice', American Economic Review, 89 (3), 349-78.

Senior, William (1836), An Outline of the Science of Political Economy, reprinted (1951), New York: A. M. Kelley.

Shackle, G. L. S. (1972), Epistemics and Economics, Cambridge: Cambridge University Press.

Smelser, Neil and Richard Swedberg (2005), 'The sociological perspective on the economy', in Neil Smelser and Richard Swedberg (eds), The Handbook of Economic Sociology, Princeton: Princeton University Press, pp. 3-26.

Sobel, J. (2002), 'Can we trust social capital?', Journal of Economic Literature, 40 (21), 139-54.

Solow, R. (1990), 'Commentary', in Richard Swedberg (ed.), Economics and Sociology, Princeton: Princeton University Press, pp. 275-82.

Spencer, Herbert (1850), Social Statics: The Conditions Essential to Human Happiness Specified, and the First of Them Developed, reprinted (1970), New York: Robert Schalkenbach Foundation.

Spolaore, E. and R. Wacziarg (2013), 'How deep are the roots of economic development?', Journal of Economic Literature, 51 (2), 325-69.

Stigler, G. (1957), 'Perfect competition, historically contemplated', Journal of Political Economy, 65 (1), 1-17.

Stiglitz, J. (2002), 'Information and the change in the paradigm in economics', American Economic Review, 92 (3), 460-501. 
Stinchcombe, Arthur (1997), 'On the virtues of the old institutionalism', Annual Review of Sociology, 23, 1-18.

Swedberg, Richard (1991), Schumpeter: A Biography, Princeton: Princeton University Press.

Swedberg, Richard (1998), Max Weber and the Idea of Economic Sociology, Princeton: Princeton University Press.

Swedberg, Richard (2003), Principles of Economic Sociology, Princeton: Princeton University Press.

Thaler, R. (2018), 'From cashews to nudges: The evolution of behavioral economics', American Economic Review, 108 (6), 1265-87.

Veblen, Thorstein (1899), The Theory of the Leisure Class: An Economic Study of Institutions, reprinted (1934), New York: The Modern Library.

Walras, Leon (1874), Elements D'économie Politique Pure (Theorie De La Richesse Sociale), reprinted (1926), Paris: Pichon et Durand Auzias.

Walras, Leon (1896), Etudes D'économie Sociale (Theorie De La Division De Richesse Sociale), reprinted (1936a), Paris: Pichon et Durand Auzias.

Walras, Leon (1898), Etudes D'économie Applique (Theorie De La Production De Richesse Sociale), reprinted (1936b), Paris: Pichon et Durand Auzias.

Weber, Max (1905), The Methodology of the Social Sciences, reprinted (1949), New York: The Free Press.

Weber, Max (1921-22), Economy and Society: An Outline of Interpretative Sociology, reprinted (1968), New York: Bedminster Press.

Weiller, P. and J. Homme (1958), 'Sociologie economique or economique sociologique?', in Georges Gurvitch (ed.), Traité de Sociologie, Paris: P.U.F., pp. 376-404.

Wicksell, Knut (1901-06), Lectures on Political Economy, reprinted (1934-35), London: Routledge and Kegan Paul.

Wicksteed, Philip (1910), The Common Sense of Political Economy, reprinted (1933), London: George Routledge and Sons.

Wieser, Friedrich von (1914), Social Economics, reprinted (1967), New York: A. M. Kelley.

Williamson, O. (1998), 'The institutions of governance', American Economic Review, 88 (2), 75-9.

Williamson, O. (2000), 'The new institutional economics', Journal of Economic Literature, 38 (3), 595-613. 